\title{
The use of Advanced and Interactive Teaching Methods in the Educational Process
}

\author{
Tojiboeva Nargiza Jumaboevna \\ Teacher of the Department of Languages \\ Samarkand Branch of the Tashkent State University of Economics
}

\begin{abstract}
This article examines the importance of modern pedagogical technologies in the acquisition and education of students' knowledge in the educational process. The article highlights such terms as teaching methods, methodology, pedagogical technology.
\end{abstract}

Key words: educational technology, interactive method, graphic organizers, heuristic method, creative reading method

\section{Introduction}

During the years of independence, as in all spheres of social, political and cultural life, radical reforms are being carried out in the field of education. As a result of effective measures taken in our country, the education system is entering a new path of development.

In the Republic of Uzbekistan, one of the important conditions for the spiritual, moral, socioeconomic development of the individual is the organization of the education system, especially primary education, on the basis of a personality-oriented educational consortium and a competencebased approach. Development in the education system is the basis for the development of society. This requires the constant introduction of innovative technologies used in the general education system, thereby speeding up the process of acquiring competencies by students and adapting them to the requirements of a developing society. The growing need for high-quality education is becoming increasingly important as an important value for the citizens of Uzbekistan. Because high-quality education is a key factor of socio-political stability and integrity.

Today's staff must be able to fully meet modern requirements, have deep knowledge, and become spiritually mature specialists. To this end, one of the important requirements of that period for our students is to receive education based on modern pedagogical knowledge in the classroom. In the course of the student's classes, textbooks, teaching aids, lecture texts, information materials, computer programs, electronic materials are used. At lectures and practical classes, advanced pedagogical technologies of the appropriate form are used. Currently, interest in the use of interactive methods, innovative technologies, pedagogical and information technologies in the educational process is growing day by day. This method teaches students to independently search for ready-made knowledge, independently learn and analyze, even independently draw conclusions. The teacher creates conditions for the development, formation, acquisition of knowledge and education of the individual in the process. In parallel, it performs a managerial, guiding function. In the learning process, the student becomes a key figure.

Modern pedagogical technologies are a set of scientific, theoretical and methodically justified new forms, methods and means of the educational process, combined into one system. At the same time, the integrity of the goal, task, activity and pedagogical result is ensured in a combination of new content, forms, methods and means, and an educational process is designed and implemented that 
guarantees the achievement of learning goals. The technological approach finds its expression, first of all, in a practical, visual structure that allows not only to depict, but also to implement the projected results. We believe that for the correct use of terms in the pedagogical process, it is necessary to know exactly their meanings. For example, in the course of our pedagogical activity, we use several terms, such as method, method, methodology, pedagogical technology, interactive methods.

The word "method" comes from the Greek word for "research", which means a way, a way to achieve a goal. The origin of the word is also reflected in its interpretation as a scientific category. A method in the most general sense is a way to achieve a goal, an activity that is organized in a certain way. When teaching the module to change sounds during speech, effective teaching methods should be used. When applying it, it is necessary to take into account the effectiveness of each method.

Teaching methods are understood as the totality of the teacher's work on solving various didactic problems, aimed at mastering the module of sound change in the speech process and methods of organizing the educational activities of students.

The teaching methodology is an integral part of the teaching methodology for the module of changing sounds in speech. The method and the method are interrelated as a whole and as a part. The methods solve only part of the educational task.

Methodology is a set of methods, methods of observing a strict sequence (algorithmic nature), a preestablished plan (rule), clearly following the system, performing a task in accordance with the goal. The concept of "methodology" is also used in connection with the study of various disciplines and is reflected in the learning process of a particular field, its content, laws, principles, forms, methods and tools.

Pedagogical technology is the content of the process of pedagogical activity, which is organized on the basis of a specific project, focused on a specific goal and guarantees the results of this goal.

Teaching technology is an algorithmic sequence aimed at designing each stage of learning separately, predetermining the expected results, rational choice of forms, methods and means used at each stage, clarifying the actions of the teacher and student.

Educational technology is a systemic process aimed at clarifying the goals and objectives of learning, designing each stage of the educational process separately, clearly defining the forms, methods and means of teaching, based on the learning outcomes in learning, the module of sound change in speech.

An interactive method is a set of teaching methods aimed at activating both the teacher and the student at the same time, being an integral part of the educational process. At the same time, it is necessary to apply interactive methods of teaching the module to change sounds in the process of speech and get effective results from this. When studying this module, you can mention such as "Venn diagram", "FSMU".

The use of graphic organizers - drawings, tables, graphs, which help in achieving the set goal when studying the module for changing sounds in the process of speech in the learning process, also guarantees high results. The method performs a spatial function if graphic organizers are used by the teacher in a finished (filled) form, as a means, in order to consolidate knowledge and develop students' thinking on the topic of the lesson. For example, from such graphic organizers you can bring such organizers as "how", "why".

The teacher organizes the learning process using various teaching methods. "The teaching method is the methods of work that the Teacher uses to develop the knowledge, skills and abilities of students, 
to form their worldview, to develop the ability to master them." The method is applied in practice through methods that correspond to its essence. and teaching expand their sphere of influence in certain conditions, have a powerful influence on education and upbringing. At this time we use a certain technique as a method, or, in other words, the technique becomes a method.

"The educational process has a twofold character: the teacher teaches, the student reads. Naturally, there is a specific goal in the activities of both the teacher and the student. The main purpose of the teacher's activity is to teach, to form in him the ability to understand, to develop a culture of feelings, moral ideas, to educate him as a spiritually pure person. The main goal of the student's activity is the fulfillment of the teacher's task, study is the assimilation of the transferred knowledge. process.

Accordingly, the teacher should create cognitive activity in students during the learning process, teach them ways of conscious and deep assimilation of literary material and use these methods to perform independent tasks.

Since literature as an academic subject has a complex multifaceted content, the lesson uses methods and techniques that contribute to the aesthetic, moral and mental development of students, the conscious, deep and thorough assimilation of knowledge, the development of their cognition and comprehension skills. For example, the teacher uses creative methods of reading, heuristic (research), research, reproductive.

\section{Conclusion}

The first stage in studying literature as an academic subject is mastering a literary work. The teacher introduces the reader to life through a work of art, fosters in him a sense of interest in contemplation and comprehension of life. Vision and perception are a prerequisite for deep, creative mastery of the work.

The personal creative experience of the student, the creative method of reading very much helps to realize these conditions. Reading a literary work is qualitatively different from reading scientific and journalistic works. Creative reading requires special attention to word, sentence, weight.

\section{References:}

1. Akhrorova, Sh. Жамият ва ижтимоий муносабатларда маънавий омиллар. Архив Научных Публикаций JSPI. - 2020. -23(1).

2. S.U. Akhrorova, (2020) "National interests and their value in social relations", Asian Journal of Multidimensional Research, Vol. 9, pp. 235-239

3. S.U. Akhrorova, (2020) "Manifestation of national spiritual features in the subjects of social policy”, ACADEMICIA: An International Multidisciplinary Research Journal, Vol. 10, pp. 21302134

4. Ахророва, Ш. У. Аспект национальных ценностей в социальной политике в Узбекистане / Ш. У. Ахророва // Credo New. - 2013. - № 4. - С. 18.

5. Ahrorova, Sh. U. The meaning of national values for social life in Uzbekistan / Sh. U. Ahrorova // Europaische Fachhochschule. - 2014. - No 3. - P. 128-129.

6. Ахророва Шахло, Жамият Ривожида Миллий Қадриятларнинг Ўрни, Научнопросветительский журнал" Наставник" , 2020/12/30 